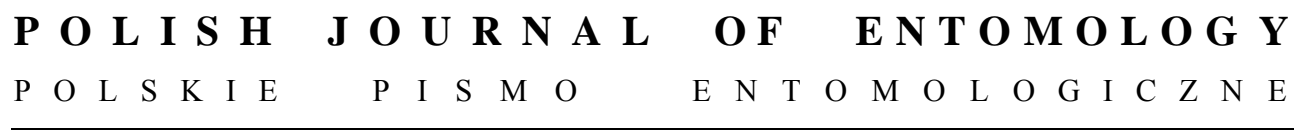

VOL. 80: $517-521$

Gdynia

30 September 2011

DOI: $10.2478 / \mathrm{v} 10200-011-0040-1$

\title{
Scythris sinensis (FELDER \& ROGENHOFER, 1775) - the first record in Poland, and some new regional records of Scythrididae (Lepidoptera)
}

\author{
ADAM MALKIEWICZ ${ }^{1}$, XAVIER DOBRZAŃSKI ${ }^{2}$ \\ ${ }^{1}$ Zoological Institute, University of Wrocław; ul. Przybyszewskiego 63/77, \\ 51-148 Wrocław, Poland, e-mail: amalki@biol.uni.wroc.pl; \\ ${ }^{2}$ Odrzańska 17/5, 50-113 Wrocław, Poland, e-mail: tawulec@o2.pl
}

\begin{abstract}
Scythris sinensis (FELDER \& ROGENHOFER, 1775) is recorded in Poland for the first time. Three other rarely encountered scythridid moths Scythris potentillella (ZELLER), Scythris knochella (FABRICIUS), Scythris cicadella (ZELLER) are given as new regional records. Comments on the distribution, biology and habitats of the moths are added.
\end{abstract}

KEY WORDS: Lepidoptera, Scythrididae, new records, distribution, Poland.

\section{INTRODUCTION}

The distribution of scythridid moths in Poland is not well known. Until a few years ago, the Scythrididae was one of the faunistically and taxonomically most neglected families of micro-moths, but the recent monograph by BARAN (2005) gives a good overview of the family. Even so, some species may still be awaiting discovery in those parts of the country that are less intensively explored. Moreover, being concealed in their early developmental stages and almost flightless (especially the females), the imagines rarely come to artificial light. According to the recent checklists by BARAN (2000) and BARAN (2005), 24 scythridid species have been found in Poland. Four of them have not been recorded since 1960 and the remainder have recent records in no more than 3 provinces.

Recent seasons have produced four interesting records in the provinces of Lower Silesia, Lubusz and Western Pomerania. Scythris sinensis (FELDER \& ROGENHOFER, 1775) is a species new to the Polish fauna. Three other rarely collected species were recorded at new localities and in new regions in Poland. 


\section{Acknowledgements}

We would like to thank Prof. Tomasz Baran (Rzeszów) for providing some of the literature sources.

This work was supported in part by Ministry of Science and Higher Education, Warsaw - grant No. 1018/IZ/S/09.

\section{SYSTEMATICS}

Scythris sinensis (FELDER \& ROGENHOFER, 1775)

Wrocław - Stare Miasto (Old Town - UTM: XS46), 17 V 2009, 1 q; 3 V 2011, 1 §;; 31 V 2011, 3 VI 2011, 2 pairs in copula, leg. X. Dobrzański; coll. A. Malkiewicz and coll. X. Dobrzański.

The specimens were collected by day from the walls of buildings in the old town centre. The locality is situated near two small squares with flower beds, with many synanthropic plants intruding on to the stone and concrete surfacing of streets under reconstruction. Among these plants, Chenopodium album is common. Other moth species inhabiting the same locality as $S$. sinensis include Chrysoesthia drurella (F.) and C. sexguttella (THNBG.) (Gelechiidae).

\section{Comments}

This species has been reported from a number of European countries: Estonia, Latvia, Lithuania, Hungary, Germany and Great Britain. It is also known from Japan, China, Korea, Taiwan, Russia and Belarus. The host plant is Chenopodium album. The caterpillars live in a loose spinning inside the young leaves at the top of the plant, concealed between the buds and leaves; the best time for collecting them is June and early July. According to BENGTSSON (1997), they are gregarious during the first two instars but thereafter live singly. They overwinter as a pupa in a dense cocoon (BENGTSSON 1997). The ecological requirements and the thermophilous, synanthropic nature of the host plant are the reasons why this moth is regularly come across in city centres (Riga, Vilnius, Barnaul). In the last mentioned one (Altai Mts.) it was recorded as common in warm spots, where the host plant was growing close to the walls of buildings (NUPPONEN \& NUPPONEN 2001). The flight period lasts from May to July but in Central Europe it is mainly in May/June and June/July (in two generations). This species can be expected in other towns and cities, including the north-eastern provinces of Poland, because it has been recorded in four southern districts of Lithuania (IVINSKIS 2004).

Scythris potentillella (ZELLER, 1847)

“Wrzosowiska Cedyńskie" Nature Reserve (UTM: VU45), 23 V 2008, 2 exx., leg. A. Malkiewicz; coll. AM. 

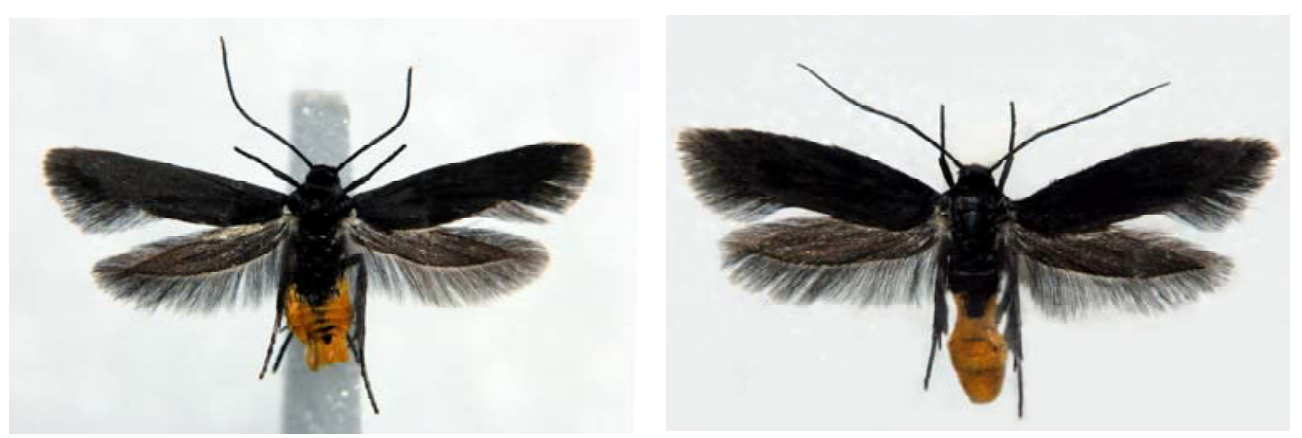

1
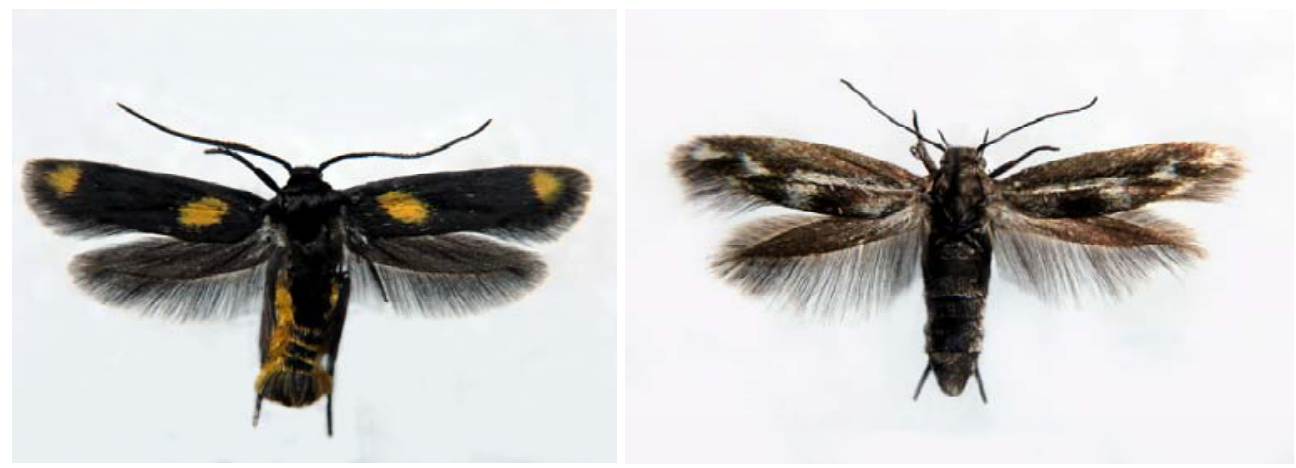

3

4

Figs 1-4. 1-3. Scythris sinensis (Felder \& ROgENHOFER, 1775), 4 - Scythris cicadella (Zeller, 1839): 1 - male, $1^{\text {st }}$ generation, 2 - female, $1^{\text {st }}$ generation, 3 - male, $2^{\text {nd }}$ generation ex larva, 4 - male, pale form (Kunice near Świecko) (photo X. Dobrzański).

The specimens were collected on a sunny day from sand dunes covered with pioneer psammophilous plants. In 2001 this species was recorded at Oleśniczka near Wrocław (BARAN 2005), in a fallow sandy field sparsely covered with secondary vegetation.

\section{Comments}

A species with two generations - in May-June and August-September - but the second one is less numerous than the first. The larvae feed exclusively on Rumex acetosella L., living solitarily in silken galleries among the basal rosettes of the foodplant. The biology and morphology of the immature stages and imagines are comprehensively described by 
BARAN (2005). Its occurrence in Poland seems to be local, but it is never abundant; so far it has been recorded in only 7 localities, none of them in north-west Poland (BARAN 2005).

\section{Scythris cicadella (ZELLER, 1839)}

Kunice near Świecko (UTM: VT79), 6 VII 2003, 1 ex., leg. A. Malkiewicz; coll. AM.

The specimen (male) was collected before sunset (ca 19:30) in a fallow sandy field sparsely covered with secondary plant communities. The vegetation was dominated by Centaurea stoebe L., Jasione montana L., Knautia arvensis (COULT.), Hieracium pilosella L., Artemisia spp. and one of the food-plants - Rumex acetosella L. The species shares this habitat with Jordanita chloros (HBN.), another inhabitant of secondary psammophilous vegetation (MALKIEWICZ \& KOKOT 2003).

\section{Comments}

The flight period of this univoltine species lasts from the end of June to July (it is most abundant in the first days of July). The caterpillars live solitarily in a silken web in the basal parts of Scleranthus perennis L., Scleranthus annuus L., Spergula morisonii BoR., Gypsophila fastigiata L. and Rumex acetosella L. (BARAN 1997). The biology and morphology of the immature stages and imagines are described in detail by BARAN (2005). Its occurrence in Poland seems local, but it is sometimes abundant; as yet, the species is known from 10 localities, but none of them in north-western Poland (BARAN 2005).

\section{Scythris knochella (FABRICIUS, 1794)}

Sudeten Mts, Góry Kamienne, Hala pod Klinem ad Rybnica Leśna (UTM: WS91), alt. 830 m, 31 VII 2010, 3 exx., leg. A. Malkiewicz; coll. AM.

The moths were collected on a hot, sunny afternoon in a flowery meadow on a steep slope with SW exposure. They were nectaring on flowers of Knautia arvensis (COULT.) and Thymus pulegioides L.

\section{Comments}

The species is univoltine, the flight period being from mid-June to late July (in the lowlands it is most abundant in the first half of July). The caterpillars live solitarily in dense, silken galleries on the leaves of Cerastium arvense L. and C. semidecandrum L. The biology and morphology of the immature stages and imagines are described in depth by BARAN (2005). It inhabits dry, open, sunny biotopes with a rich herbaceous vegetation. Its occurrence in Poland is considered local, but it is sometimes abundant; so far, the species has been found in 14 localities, but none of them in mountain areas. The species is new to the Sudeten Mts.

Here it should be noted that this species could at first sight be confused with the newly described central Asian species, Scythris reticulella NUPPONEN, 2010, which belongs to the knochella species group, but the streak in the fold of its forewing is pale brown (not white), and in the male genitalia the valvae and aedeagus are distinctly different (NUPPONEN 2010). 


\section{REFERENCES}

BARAN T. 1997. New data on the food-plants of Scythris cicadella (ZELLER, 1839) (Lepidoptera, Scythrididae). Wiadomości Entomologiczne 16: 56.

BARAN T. 2000. Scythrididae. [In:] Buszko J. \& NowACKi J. (eds). The Lepidoptera of Poland. A Distributional Checklist. Polish Entomological Monographs 1: 35-36.

BARAn T. 2005. The Scythrididae (Lepidoptera: Gelechioidea) of Poland. Polish Entomological Monographs 3. Poznań - Torun, 269 pp.

Bengtsson B.Á. 1997. Scythrididae. [In:] Huemer P., Karsholt O. \& Lyneborg L. (eds). Microlepidoptera of Europe 2: 1-131. Apollo Books, Stenstrup.

IVINSKIS P. 2004. Lepidoptera of Lithuania. Annotated catalogue. Institute of Ecology of Vilnius University, $380 \mathrm{pp}$.

MAlKIEwICZ A., KокOT A. 2003. Uwagi o aktualnym występowaniu Jordanita chloros (HÜBNER, 1813) (Lepidoptera: Zygaenidae) w Polsce. Przegląd Zoologiczny Wrocław 47: 205-209.

NUPPONEN K. 2010. Notes on Scythrididae from the Turanian region, with descriptions of six new species (Lepidoptera: Scythrididae). SHILAP Revista de Lepidopterologia 38: 267-285.

NUPPONEN K., NUPPONEN T. 2001. Notes on the scythridid fauna of the Altai Mountains, with descriptions of four new species (Lepidoptera, Scythrididae). Entomologica Fennica 12: 81-93.

Received: July 04, 2011

Accepted: July 22, 2011 